\title{
THE INFLUENCE OF COUNTRY OF ORIGIN, PROFITABILITY, AND LEVERAGE ON ENVIRONMENTAL DISCLOSURE (EMPIRICAL STUDY ON ENVIRONMENTALLY SENSITIVE COMPANIES)
}

\author{
Siti Haninah Nadiva*1, Said Muniruddin ${ }^{* 2}$ \\ ${ }^{1,2}$ Accounting Department, Faculty of Economics and Business, Syiah Kuala University \\ e-mail: shaninadv@gmail.com ${ }^{* 1}$, saidmunir@fe.unsyiah.ac.id ${ }^{* 2}$
}

\begin{abstract}
In recent years the impact of industrial activities on environment has increased people's concern. This situation gives pressure from society to management to develop environmental management and report their environmental activities. Therefore, this study aims to examine the influence of country of origin, profitability, and leverage on environmental disclosure. This study analyses the disclosure of environmental activities of four industrial sectors in Indonesia Stock Exchange (IDX) for 2017 period. The study focuses on four sectors identified as more sensitive to environment namely agriculture, basic and chemical, mining, and consumer goods industry. Forty (40) companies selected as sample, of which 10 companies represent each industry. The environmental disclosure is measured by 34 environmental indicators from GRI 4.0. Multiple linear regression analysis is utilized for the hypothesis testing within the study. The result of this study revealed that all independent variables do not simultaneously influence the dependent variable. There is no influence of country of origin, profitability, and leverage on environmental disclosure
\end{abstract}

\section{Keywords: Environmental Disclosure, Country of Origin, Profitability, Leverage}

\section{Introduction}

Nowadays, the condition of environment around the world is getting worse (nationalgeographics.com). One of the main contributors to this problem is due to the industrialization in various countries. Industrial activities such as air pollution, industrial waste, exploitation of land, and the excessive use of natural resources has brought various negative impacts on the environment. This condition leads to the increase of concern from various parties such as governments, environmentalists, shareholders, stakeholders, and creditors (Lisa and Herman 2016). Facing the increasing attention from various parties, companies are pressured to conduct environmentally based operations and produce information related to their environmental performance (Monteiro and Guzman, 2010 in Akbas, 2014).

In Indonesia we also experienced the impact of carelessness of companies that provoke action from stakeholders to stop what the company is doing. This pressure-related action from stakeholders happened in 2007 where local community requested companies to stop their operations in the area, and through the ministry of environment the government issued instructions to relevant companies to stop all operations until the environmental impact assessment has been completed and approved. This happened in Sambas West Kalimantan to groups of Wilmar International, which are PT. Wilmar Sambas Plantation (WSP), Agro Nusa Investama (ANI), and Buluh Cawang Plantation (BCP) in cases of forest destruction, conversion of plantation land into peat lands, to illegal forest burning. . These cases prove that companies have lack of awareness to the environment and it makes many environmental organizations emerge in the community to share awareness about environment protection. Regulations which aimed to give environment protection and sustainable development also began to be declared. Companies are now expected to address the impact of their operations on the environment and society at large (Innocent et al., 2014)

In responding to the pressures made by stakeholders, companies have sought to find ways to mitigate adverse environmental impacts. They also have begun to present environmentally-based financial reporting in order to maintain company's viability through support from stakeholders. To improve environmental conservation, accounting implements voluntary disclosure to the financial statements, related 
to environmental costs. For the assessment of the social impact done by the reporting organization, The Global Reporting Initiative (GRI) standards were made as the guideline. GRI created according to international labor practices and the environmental impact by conducting an independent audit. GRI gives interpretation on actions that can be taken or considered in making decision on reporting environmental activities. It also provides detailed principles and indicators for reporting content on all aspects of company performance, accountability, and setting report boundary.

Several studies have been conducted to explain the factors that influence the company's environmental responsibility disclosure policy. Jue and Xiaobo (2014) proved that firm size, financial risk, growth ability, and profitability are factors that are considered as corporate attributes that have significantly impact on companies' environmental information disclosure. Chaklader and Gulati (2015) also stated internal factors that may affect environmental disclosure include: profitability, size, type of industry, financial leverage, multinational status and environmental certification.

Zhang, Guo, Li, and Wang (2009) research result proves that larger companies and profitable companies more likely to disclosure its environmental activity, which means larger companies feel more responsibility to make their environmental disclosure than smaller company. Akbas (2014) gives the same research result that stated that firms with high profitability ratios can reveal more information to interfere with negative concerns derived from the advantages of profitability and increase their credibility among investors, while research by D’Amico, Fontana, Solimene, and Coluccia (2014) states that profitability measured with ROI (Return on Investment) does not have any significant impact to environmental disclosure. It is in line with the research result of Julianto and Sjarief (2016) that measured profitability with profit margin stated that profitability does not have significant impact for company to disclose their environment disclosure.

Based on the background, this research is attempting to use a stakeholder and legitimacy theoretical basis to test and analyze other factors in firm characteristics that are thought to have an influence and relation to the environmental disclosure.
Therefore, due to the differences of previous research results on the influence of profitability and leverage on the environmental disclosure will be used again in this research with an additional variable, which is the country of origin of company. In this research the annual report of companies listed in Indonesian Stock Exchange from 2017.

The objectives of this study are to examine whether:

1. The influence of whether the country of origin, profitability, and leverage influences company's environmental disclosure.

2. To determine whether the country of origin influences company's environmental disclosure.

3. To determine whether the profitability influences company's environmental disclosure.

4. To determine whether the leverage influences company's environmental disclosure.

\section{Literature Review And Hypothesis Development Stakeholder Theory}

Stakeholders have been defined as a group of people that have interest in a company because they get impact or are affected by the company's activities. Companies in operating their activity must not only think the good for their business but also impacts they may cause to the environment, society, and other parties. Hadi (2009) in (Hidayat, 2017) states that stakeholders are all parties who have relation with companies because they get influence directly or indirectly by the companies activities. Stakeholder theory believes that the sustainability of a business is depending on how the companies balance their interests, the stakeholders and other party's interest. Thus, the existence of a company is strongly affected by the support given by stakeholders to the company (Tamba, 2011)

\section{Legitimacy Theory}

According to Guthrie and Parker (1990) to explain the environmental and social disclosure, the legitimacy theory is one of the most used theories. Legitimacy theory focuses on the interaction between companies and society. This theory states that companies are part of the community so they should 
pay attention to social norms of society to make the company more legitimate. O'Donovan (2000) concluded that organizational legitimacy can be seen as something that society gives to the company and something the company wants or sought from a society. $\mathrm{He}$ also states that if there are differences between company value and social value, company need to adjust their value to the social framework to get the legitimation from society. The existence of company depends on how society consider their activities are legitimate or not and then contract will arise between the company and society. Therefore one of the strategies a company can use to be legitimized by the community is by disclosing their environmental activities. To gain legitimacy, corporate organizations must communicate environmental activities being exposed to the social environment (Berthelot \& Robert, 2011). . As Juhmani (2014) stated, companies convey to the world its position in political and economic by creating an image or symbolic impression of itself through the disclosure of their social and environmental activities.

\section{Environmental Disclosure}

Environmental disclosure is a voluntary disclosure. The disclosure of this information is voluntary because there are no specific regulations governing the disclosure of environment activities in the company's financial and annual reports. According Ghozali and Chariri (2007), environmental disclosure is a process used by companies to disclose information relating to corporate activities and their effects on environmental conditions. The information that contain in environmental disclosure will helps stakeholders and other users of it to evaluate the company's performance on environment and allowing them to make right decision. Disclosing their environmental activities will not give direct profit or benefits to companies, but it expected to increase companies goodwill or reputation.

The demand to give protection to environment has been increasing around the world, because of it few guidelines to disclose environmental activities of companies have been made and keep enhancing its quality. The GRI is the first and most widely adopted global standard for sustainability reporting. GRI helps company to communicate with their stakeholder about their impact in sustainability reporting such as environmental issues.

\section{Country of Origin}

Companies in developed countries tend to disclose more about their environmental activity because of the pressure from government regulation and stakeholders. There are many things that cause companies to make environmental disclosure such as government action, stakeholders pressure, accounting regulation, national culture and economy ( Hashim, Mahadi, \& Amran, 2015).

This study differentiates company on IDX into two kinds: International companies and domestic companies. International companies are those founded in another country, outside Indonesia but located in Indonesia. Domestic companies are those that founded in Indonesia and located in Indonesia.

\section{Profitability}

Profitability is companies' ability to generate profit. Harahap (2011) defines profitability ratios as a companies' ability to earn profits through all available sources, such as sales activities, cash, capital, number of employees, and number of branches. In order to raise good capital profitable companies would likely to distinguish themselves from less profitable companies through disclosing voluntary information of the companies' activities. To measure the profitability of the company this study use ROA (Return on Asset). Data of ROA can be found in annual report.

\section{Leverage}

Leverage is an investment strategy involving the borrowed funds to finance asset. According to Purnasiwi and Sudarno (2011) leverage is a tool to measure how much companies depend on creditors in financing the companies' assets. Companies that have high leverage level rely heavily on external loans to finance their assets. While companies that have low leverage level more likely rely on their own capital to finance their assets. In this study leverage of company will be measured with Debt to Equity Ratio (DER).

\section{Hypotheses}

Based on discussion above on research background and theoritical framework, this study hypotheses are: 
H1: Country of Origin, Profitability, and Leverage simultaneously influence the environmental disclosure.

$\mathrm{H} 2$ : Country of Origin positively influences the environmental disclosure.

H3: Profitability positively influences the environmental disclosure.

H4: Leverage positively influences the environmental disclosure.

\section{Research Methodology \\ Research Design}

This study's purpose is to indicate the influence of country of origin of company, profitability, and leverage on environmental disclosure using hypotheses. Hypothesis-testing research studies are those where the researcher tests the hypotheses of causal relationships between variables (Kothari, 2004:34). The type of investigation in this study is correlation study, which is the assessment of the influence of independent variables towards the dependent variable. In this study, the linkage among variables is going to be examined.

\section{Population and Sample}

In this research the population is taken from Indonesian Stock Exchange (IDX) website focusing on four industrial sectors, identified as more sensitive to environment, namely agriculture, basic industry and chemical, consumer goods industry, and mining companies that listed in IDX 2017. Fourty companies is selected by criteria set that made up the sample of which 10 companies represent each sectors that listed in Indonesian Stock Exchange (IDX) for the period 2017. The criteria set will add the number of companies selected as the sample from the population in this research as follows:

1. Selected companies in agricultural industry.

2. Selected companies in basic and chemical industry.

3. Selected companies in consumer goods industry.

4. Selected companies in mining industry.

Based on above criteria, the sample used in this research is shown in table Table 3.1 as follows.

\begin{tabular}{|c|l|c|}
\hline No & \multicolumn{1}{|c|}{ Criteria of Sample Selection } & Sample \\
\hline 1. & $\begin{array}{l}\text { The number of companies that } \\
\text { selected in agriculture industry }\end{array}$ & 10 \\
\hline 2. & $\begin{array}{l}\text { The number of companies that } \\
\text { selected in basic and chemical } \\
\text { industry }\end{array}$ & 10 \\
\hline 3. & $\begin{array}{l}\text { The number of companies that } \\
\text { selected in consumer goods } \\
\text { industry }\end{array}$ & 10 \\
\hline $4 . \quad \begin{array}{l}\text { The number of companies that } \\
\text { selected in mining industry }\end{array}$ & 10 \\
\hline Total Companies & 40 \\
\hline \multicolumn{2}{|l|}{ Multiple by the year of observation } & x1 \\
\hline Firm-year observations & 40 \\
\hline
\end{tabular}

Source: Data Processed (2019)

\section{Sources and Data Collection Method}

In this research, the source of data used is secondary data. Secondary data means data that are already available, either be published data or unpublished data (Kothari, 2004:95). The data sourced from the annual report published in Indonesia Stock Exchange (IDX) for period 2017. The collection method of this study is using documentation method, which is taken from company's annual report for period 2017 which published on Indonesia Stock Exchange (IDX).

\section{Variables Operationalization \\ Dependent Variable (Y)}

Dependent variable in this study is measured using scoring index developed in accordance with the criteria listed in the GRI guidelines. This index is usually called Sustainability Disclosure Index (SDI). The sustainability disclosure index in this study is adopted directly from GRI G4 guideline. The global reporting GRI G4 index consist of 91 items on social, economic, and environmental.

This study uses content analysis to measure the extent of sustainability disclosure in the sustainability report. Content analysis is a method of text codification from same criteria to be categorized in different group depends on the criteria. The environmental disclosure index is obtained by dividing between the total score gained by each firm with the maximum score of the items used in this study (Hidayat, 2017). The maximum score based on the item used is 34 items. 


\section{Environmental Disclosure Index (EDI) $=\sum \frac{\text { The total score obtained }}{\text { The total score of item lists }}$}

\section{Independent Variable $(X)$ \\ Country of Origin}

Country of origin of company is where the parent company is. In this study country of origin of company was measured by a dummy variable, where 1 = international company and $2=$ domestic company (Stanton, 2012).

\section{Profitability}

Profitability is a number that shows the ability of a company to generate profits at the level of asset sales, and certain capital stock. Profitability is an indicator of the management performance in managing the company's wealth shown by the ability of company to gain profit. In this study, the independent variable that used to measured profitability of company is Return on Asset (ROA) (Rofiqkoh \& Priyadi, 2016). ROA measures by:

$$
\text { Return on Asset }(\text { ROA })=\frac{\text { Net Profit }}{\text { Total Assets }}
$$

\section{Leverage}

Leverage is a company's financial risk that describes the relationship of total debt owned by the company to its total assets (Andriana, 2013). In this study financial leverage is measure by DER (Debt to Equity Ratio). This ratio show how much debt a company is using to finance its assets relative to the value of stakeholders' equity. Der is the ratio of total liabilities divided by stakeholders' total equity (Pradnyani \& Sisdyani, 2015) The formula is:

$$
\text { Debt to Ratio }(\text { DER })=\frac{\text { Total Liabilities }}{\text { Total Equity }}
$$

\section{Research Results And Discussion \\ Research Results \\ Description of Research Object}

The purpose of this study is to test the influence of country of origin, profitability, and leverage on environmental disclosure on environmentally sensitive company listed in Indonesian Stock Exchange (IDX) period 2017. In this study, the object of the study was selected by using purposive sampling method by setting few criteria. Based the criteria 40 companies in 4 sector industries was obtained.

Data analysis was performed using the method of multiple linear regression analysis. The first step is to test the classical assumption test, namely the normality test, multicollinearity test, heteroscedasticity test. Then, hypothesis testing is done by testing the $\mathrm{t}$ test and also multiple regression analysis by seeing a significant value at $0.05(5 \%)$. Based on the results of the classical assumption test shows that the research data is normal and free from multicolonearity, heteroscedasticity and autocorrelation.

Multiple Linear Regression Analysis Results
\begin{tabular}{|l|r|r|}
\hline \multirow{2}{*}{ Model } & \multicolumn{3}{|c|}{ Unstandardized Coefficients } \\
\cline { 2 - 3 } & B & \multicolumn{1}{|c|}{ Std. Error } \\
\hline (Constant) &, 307 &, 044 \\
COO &,- 080 &, 077 \\
ROA &,- 031 &, 025 \\
DER &, 042 &, 039 \\
\hline
\end{tabular}

Source: Output SPSS (2018)

Multiple linear regression model of this research is written as follows:

$$
\mathrm{Y}=0.307-0.080 \mathrm{X1}-0.031 \mathrm{X} 2+0.042 \mathrm{X3}+\mathrm{e}
$$

Therefore, the linear regression model in this research is:

$$
\begin{gathered}
\text { VDI }=0.307-0.080 \text { COO }-0.031 \text { ROA }+\mathbf{0 . 0 4 2} \\
\text { DER }+ \text { e }
\end{gathered}
$$

The dependent variable $(\mathrm{Y})$ is the index of enviromental disclosure that calculated from the number of items that revealed by the company divided by the total number of disclosures items with the total of 34 items. While, the variable $\mathrm{X}$ represents by the determinants of environmental disclosure which are country of origin, profitability, and leverage. COO uses dummy variable as its proxy. Profitability uses Return on Asset (ROA) as its proxy. Meanwhile, leverage uses Debt to Equity Ratio (DER) as its proxy. From the results of the regression equation above can be explained as follows:

1) If the country of origin variable increases $1 \%$, it will increase the extent of voluntary disclosure of the company's annual report $-0.080(-8 \%)$ and vice versa. Negative regression coefficient shows that the opposite relationship. If the independent variables increase, then the dependent variable will 
decreases. The higher the amount of country of origin, the lower the extent of environmental disclosure.

2) If the profitability variable increases $1 \%$, it will decrease the extent of voluntary disclosure of the company's annual report $-0.031(-3.1 \%)$ and vice versa. Negative regression coefficient shows that the opposite relationship. If the independent variables increase, then the dependent variable will decreases. The higher the amount of profitability the lower the extent of environmental disclosure.

3 ) If the leverage variable increases $1 \%$, it will increase the extent of voluntary disclosure of the company's annual report $0,042(4.2 \%)$ and vice versa. Negative regression coefficient shows that the opposite relationship. If the independent variables increase, then the dependent variable will decreases. The higher the amount of leverage the lower the extent of environmental.

\section{T-Statistical Test Result}

T-statistical test basically conducted to examine the independent variables in explaining the variation of the dependent variable. T-statistic test assesses how far the effect of an independent variable on dependent variable. The result of $t$-statistical test is as follows:

\section{T-Statistical Test}

\begin{tabular}{|rr|rr|}
\hline \multicolumn{1}{|c|}{} & \multicolumn{3}{|c|}{ Sig. } \\
\hline & & \multicolumn{2}{|c|}{, 000} \\
& 6,955 & &, 306 \\
$-1,038$ & &, 216 \\
$-1,259$ & &, 294 \\
\hline
\end{tabular}

Source: Output of SPSS (2018)

According to Table 4.6, the results of tstatistical test can be described as:

1) The country of origin variable (X1) has a value of $\mathrm{t}-1.038$ with the significance level of 0.306 . The significance value is greater than the significance level of $0.05(5 \%)$. Therefore, it shows that country of origin does not have effect on environmental disclosure. Thus, the second hypotheses (H2) is rejected.

2) The profitability variable (X2) has a value of $t$ 1.259 with the significance level of 0.216 . The significance value is greater than the significance level of $0.05(5 \%)$. Therefore, it shows that profitability does not have effect on the environmental disclosure. Thus, the third hypotheses $(\mathrm{H} 3)$ is rejected.

3) The leverage variable (X3) has a value of 1.064 with the significance level of 0.294. The significance value is greater than the significance level of $0.05(5 \%)$. Therefore, it shows that leverage does not have effect on the environmental disclosure. Thus, the fourth hypotheses (H4) is rejected.

\section{F-Statistical Test Result}

F-statistical test is basically conducted to test the influence of all independent variables concurrently on the dependent variable. The results of F-test are as in the table below:

\section{F-Test Results}

ANOVA ${ }^{a}$

\begin{tabular}{|l|r|r|r|c|c|}
\hline Model & $\begin{array}{c}\text { Sum of } \\
\text { Squares }\end{array}$ & Df & $\begin{array}{c}\text { Mean } \\
\text { Square }\end{array}$ & F & Sig. \\
\hline Regression &, 120 & 3 &, 040 & 1,164 &, $337^{b}$ \\
Residual & 1,233 & 36 &, 034 & & \\
Total & 1,352 & 39 & & & \\
\hline
\end{tabular}

a. Dependent Variable: ED

b. Predictors: (Constant), DER, ROA, COO

Source: Output of SPSS (2018)

It can be seen that the significant value is 0,337 and lower than the significance level of $0.05(5 \%)$. As the results, the first hypotheses (H1) is accepted because the independent variables are do not affect the voluntary disclosure.

\section{Coefficient Determination Test $\left(\mathbf{R}^{2}\right)$}

Coefficient determination test conducted to know the value that the independent variables can explain the dependent variable.

\section{Coefficient Determination Result}

\begin{tabular}{|l|r|r|}
\hline Model & \multicolumn{1}{|c|}{ R } & \multicolumn{2}{|c|}{ R Square } \\
\hline 1 &, $297^{\mathrm{a}}$ & \multicolumn{1}{|c}{, 088} \\
\hline
\end{tabular}

Source: Output of SPSS (2018)

The table above shows that the R Square value is 0.088 . It means that $8.8 \%$ from the change in dependent variable can be explained by the country of origin (X1), profitability (X2), and leverage (X3). 
Meanwhile, the others $91,2 \%$ can be influenced by other variables that are not used in this research.

\section{Discussion}

According to the results of multiple linear regressions that have been tested in this research, the impact of each independent variable on dependent variable is discussed as follows:

\section{The Influence of Country of Origin, Profitability, and Levearge to Environmental Disclosure.}

Based on the results of the F- Test, the significance value of F-Test is 0.337 and is bigger than the significance level of $0.05(5 \%)$. As the results, all the independent variables do not affect the dependent variable. Thus, the independent variable of country of origin, profitability, and leverage do not affect the environmental disclosure. Hence, $\mathrm{H} 1$ is rejected.

\section{The Influence of Country of Origin (X1) to Envionmental Disclosure.}

The country of origin (X1) has a value of $t$ 1.308 with the significance level of 0.306 is higher than the significance level of 0.05 (5\%). It shows that the country of origin does not have effect on the environmental disclosure in companies sampled in this study. This result is contradictive with the results from Einwiller, Ruppel, and Schn (2016) which stated that country of origin effects reveal that company are still impacted by their home-land expectations. In addition, there is research in corporate reputation that shows stakeholders have higher visibility and awareness of companies in their home country (Fombrun and van Riel, 2004), which increase the pressure for companies to respond the stakeholder at home. However, this results is the same with the results from Patricia Staton (2011) that did research in Thailand Listed companies. Thus, $\mathrm{H} 2$ is rejected.

\section{The Influence of Profitability (X2) to Environmental Disclosure.}

The profitability (X2) has a value of $t-1.259$ with the significance level of 0.216 is higher than the significance level of $0.05(5 \%)$. It shows that the profitability does not have effect on the environmental disclosure in this study. this results is the same with the results from Julianto and Sjarie (2016) that did research about environmental disclosure.
Profitability is measured by Return on Asset (ROA) that does not effect environmental disclosure. It means that high profitability companies do not necessarily carry out more social activities because the company is oriented to profit alone. In other words, when a company has a high level of profit, the companies (management) do not considers to report things that can disrupt information about the company's financial success. On the contrary, when the level of profitability is low, they expect users of report to read good news about company performance. The good news can be in the form of environmental social activities carried out by the company. As the results of this research, $\mathrm{H} 3$ is rejected.

\section{The Influence of Leverage (X3) to Environmental Disclosure.}

The leverage (X3) has a value of t 1.064 with the significance value 0.294 which is higher than the significance level of $0.05(5 \%)$. It shows that the leverage of companies negatively effect the environmental disclosure in this study. This result is contradictive with the results from Juhmani (2014) that conduct research about environmental disclosure in Bahrain that leverage effect the companies environmental disclosure. Meanwhile, this result is in accordance with the research conduct by Dibia and Onwuchekwa (2015) that did the research in Nigeria.

According to Aksu and Kosedag (2006) in Kilic \& Kuzey (2017) that conduct research in Turkey, the explanation for the insignificant relationship is the conflict between creditors and manager is not a big issues in Turkish companies. Therefore, based on the result of the research high financial leverage companies will decrease the information of environmental disclosure. Hence, $\mathrm{H} 4$ is rejected.

\section{Conclusion, Limitation, And Suggestion Conclusion}

Based on the results and discussion of the research that has been stated, it can be concluded that:

1) The country of origin does not affect the voluntary disclosure of financial report in environmentally sensitive companies listed on Indonesia Stock Exchange year 2017.

2) The profitability does not affect the voluntary disclosure of financial report in environmentally 
sensitive companies listed on Indonesia Stock Exchange year 2017.

3) The leverage does not affect the voluntary disclosure of financial report in environmentally sensitive companies listed on Indonesia Stock Exchange year 2017.

4) The country of origin, profitability, and leverage does not affect the voluntary disclosure of financial report in environmentally sensitive companies listed on Indonesia Stock Exchange year 2017.

\section{Limitation of the Research}

This research has limitations that can be considered for further research in order to obtain better results in the future, which described as follows:

1) This research only used companies that listed in the Indonesia Stock Exchange. Therefore, there are not many International companies to test the country of origin variable.

2) This study only used three independent variables as the proxy for environmental disclosure which are country of origin, profitability, and leverage. Meanwhile, there are many other activities of corporate governance can be used as the independent variable.

3) This research only used 10 companies in 4 sectors industries. Meanwhile, more companies will give more accurate results.

\section{Suggestion for Future Research}

Based on the results, discussions, conclusions and some limitations in this study, there are some suggestions that can be given in order to obtain the better results for further research. The following are some suggestions that can be considered in doing the further research about the voluntary disclosures:

1. The research can be conducted by increasing another independent variables that exist.

\section{References}

Akbas, H. E. (2014). Company Characteristics and Environmental Disclosure: An Empirical Investigation on Companies Listed on Borsa Istanbul 100 Index. The Journal of Accounting and Finance, 145-164.

Akrout, M. M., and Othman, H. B. (2013). A Study of the Determinants of Corporate Environmental Disclosure in MENA Emerging Markets .
Journal of Reviews on Global Economics, 4659.

Albertini, E. (2014). A Descriptive Analysis of Environmental Disclosure: A Longitudinal Study of French Companies. J Bus Ethics, 233254.

Ali, W., Frynas, J. G., and Mahmood, Z. (2017). Determinants of Corporate Social Responsibility (CSR) Disclosure in Developed and Developing Countries: A Literature Review. Corporate Social Responsibility and Environmental Management.

Al-Tuwaijri, S., II Hughes, K., and Christensen, T. E. (2004). The Relations Among Environmental Disclosure, Environmental Performance, and Economic Performance: A Simultaneous Equations Approach. Accounting, Organizations and Society, 447-471.

Andriana, D. (2013). Pengaruh Leverage dan Profitabilitas Terhadap Pengungkapan Tanggung Jawab Sosial Perusahaan Pertambangan Yang Terdaftar Di Bursa Efek Indonesia. Jurnal Riset Akuntansi dan Keuangan, 1(2), 161-173.

Bassey, E., Sunday, O., and Okon, E. (2013). The Impact of Environmental Accounting and Reporting on Organizational Performance of Selected Oil and Gas Companies in Niger Delta Region of Nigeria. Research Journal of Finance and Accounting, 4(3), 57-73.

Berthelot, S., and Robert, A.-M. (2011). Climate change disclosures: An examination of Canadian oil and gas firms. Issues in Social and Environmental Accounting, 5, 106-123.

Bryman, A., and Bell, E. (2013). Business Research Methods. In A. Bryman, and E. Bell, Business Research Methods (Fourth Edition ed., p. 48). New York: Oxford University Press.

Burgwal, D., and Vieira, R. O. (2014). Environmental Disclosure Determinants in Dutch Listed Companies. USP, São Paulo, 60-78.

Chaklader, B., and Gulati, P. A. (2015). A Study of Corporate Environmental Disclosure Practices of Companies Doing Business in India. Global Business Review, 2(1), 321-335.

Christophe, T., and Filipovic, M. (2008). The Extent and Determinants of Disclosure of Global Reporting Initiative Guidelines: Australian Evidence. Journal of Contemporary Issues in Business and Government, 14(2), 17-40.

Connelly, J., and Limpaphayom, P. (2004). Environmental Reporting and Firm Performance: evidence from Thailand. The Journal of Corporate Citizenship,, 13, 137-149. 
D'Amico, E., Coluccia, D., Fontana, S., and Solimene, S. (2014). Factors Inf luencing Corporate Environmental Disclosure. Business Strategy and the Environment.

Deegan, C. (2011). The Legitimising Effect of Social and Environmental Disclosures - A Theoretical Foundation. Accounting Auditing and Accountability Journal, 15(3), 282-311.

Dibia, N., and Onwuchekwa, J. C. (2015). Determinants of Environmental Disclosures in Nigeria: A Case Study of Oil and Gas Companies. International Journal of Finance and Accounting, 4(3), 145-152.

Einwiller, S., Ruppel, C., and Schn, A. (2016). Harmonization and differences in CSR reporting of US. International Journal, 2, 1-26.

Ghozali , I., and Chairiri, A. (2007). Teori Akuntansi. Semarang: Universitas Dipenogoro.

Guthrie, J., and Parker, L. (1990). Corporate social disclosure practice: a comparative international analysis. Advances in Public Interest Accounting, 159-179.

Hadjoh, R. A., and Sukartha, I. (2013). Pengaruh Ukuran Perushaan, Kinerja Keuangan dan Eksposur Media Pada Pengungkapan Informasi Lingkungan. Jurnal Akuntansi, 4(1), 1-18.

Harahap, S. S. (2011). Harahap, Sofyan Syafri. Analisis kritis atas Laporan Keuangan. Jakarta: Rajawali Pers.

Hashim, F., Mahadi, N. D., and Amran, A. (2015). Corporate Governance and Sustainability Practices in Islamic Financial Institutions: The Role of Country of Origin . Procedia Economics and Finance, 36-43.

Hidayat, M. (2017). Faktor-Faktor Yang Mempengaruhi Pengungkapan Sukarela Pada Laporan Tahunan Sektor Perbankan di Bursa Efek Indonesia. Dimensi, 6(1), 151-172.

Jue, P., and Xiaobo, W. (2014). An Empirical Study on Impacts of Environmental Regulation on Environmental Information Disclosure of Listed Companies of China: Based on Researches on Listed Companies in Nonferrous Metal Industry. Canadian Social Science, 10(2), 113-123.

Juhmani, O. (2014). Determinants of Corporate Social and Environmental Disclosure on Websites: the Case of Bahrain. Universal Journal of Accounting and Finance, 2(4), 77-87.

Julianto, M., and Sjarief, J. (2016). Analisis Pengaruh Kinerja Lingkungan Manajemen Laba, Ukuran Perusahaan, dan Profitabilitas Terhadap Pengungkapan Lingkungan Pada Perusahaan Manufaktur Yang Terdaftar Di Bursa Efek Indonesia. Jurnal Akuntasni, 141-171.
Laan Smith, J. d., Adhikari, A., and Tondkar, R. (2005). Exploring differences in social disclosures internationally: A stakeholder perspective. Journal of Accounting and Public Policy, 24(2), 123-151.

Manaf, N. A., Atan , R., \& Mohamed, N. (2018). Environmentally Sensitive Companies Social Responsibility and Reporting: A Study Of Malaysian Companies . Accounting and Business .

O'Donovan, G. (2000). Legitimacy theory as an explanation for corporate environmental disclosures. Victoria University of Technology, 1-351.

Ortas, E., Gallego-Alvarez, I., and Etxeberria, A. (2014). Financial Factors Influencing the Quality of Corporate Social Responsibility and Environmental Management Disclosure: a Quantile Regression Approach. Corporate Social Responsibility and Environmental Management.

Pradnyani, I. A., and Sisdyani, A. E. (2015). Pengaruh Ukuran Perusahaan, Profitabilitas, Leverage, dan Ukuran Dewan Komisaris Pada Pengungkapan Tanggung Jawab Sosial Perusahaan. E-Jurnal Akuntasi Universitas Udayana, 11(2), 384-397.

Purnasiwi, J., and Sudarno. (2011). Analisis Pengaruh Size, Profitabilitas dan Leverage terhadap Pengungkapan CSR pada Perusahaan yang Terdaftar di Bursa Efek Indonesia. Universitas Diponegoro.

Rofiqkoh, E., and Priyadi, P. M. (2016). Pengaruh Profitabilitas, Leverage, dan Ukuran Peursahaan Terhadap Pengungkapan Tanggung Jawab Sosial Perusahaan. Jurnal Ilmu dan Riset Akuntansi :, 5(10), 1-18.

Rustiarini, N. (2011). Pengaruh Struktur Kepemilikan Saham pada Pengungkapan Corporate Social Responsibility. Jurnal Ilmiah Akuntansi dan Bisnis, 6(1).

Saputra, S. E. (2016). Pengaruh Leverage, Profitabilitas dan Size Terhadap Pengungkapan Corporate Social Responsibility Pada Perusahaan di Bursa Efek Indonesia. Journal of Economic and Economic Education, 5(1), 7589.

Sekaran, Uma and R. Bougie. 2010. Research Method for Business. West Sussex, United Kingdom: Wiley.

Sembiring, E. (2005). Karakterisitik Perusahaan dan Pengungkapan TanggungJawab Sosial (Study Empiris pada Perusahaan yang tercatat di Bursa Efek Jakarta). Jurnal Magister Akuntansi, 6, 6985. 
Smith, M., Yahya, K., and Amiruddin, A. (2007). Environmental disclosure and performance reporting in Malaysia. Asian Review of Accounting, 15, 185-199.

Stanton, P. (2012). Determinants of Environmental Disclosure in Thai. International Journal of Accounting and Financial Reporting, 2(1), 99115.

Tamba, E. H. (2011). Pengaruh Struktur Kepemilikan Saham Terhadap Pengungkapan Tanggung Jawab Sosial Perusahaan (Studi Empiris Pada Perusahaan Manufacturing Secondary Sectors Yang Listing di BEI 2009). Universitas Dipenogoro.

Zhang, J., Guo, H., Li, B., and Wang, W. (2009). The Influence of Financial Factors on Environmental Information Disclosure in China Chemical Industry. International Journal of Global Environmental Issues, 9(3). 